\title{
PENGEMBANGAN DAYA SAING SYAR'IY: SEBUAH REFORMULASI KEPEMIMPINAN PESANTREN
}

\author{
Aminatuz Zahroh \\ Institut Agama Islam Syarifuddin Lumajang \\ aminatuzzahroh68o@gmail.com
}

\begin{abstract}
Abstrak
Dalam decade terakhir ini, proses globalisasi dan berbagai inovasi baru telah terjadi di berbagai bidang kehidupan. Salah satu imbas dari globalisasi ini adalah pesantren sebagai tempat menggali ilmu dan menghasilkan pengetahuan agama perlu bersaing untuk kelangsungan hidup. Persaingan tersebut meliputi mutu, harga, layanan, prestasi santri dan outputnya. Pemenang dari persaingan itu adalah pesantren yang memiliki SDM yang berkualitas dalam iman, taqwa, kemampuan, ilmu pengetahuan, teknologi dan keterampilan. Salah satu cara untuk memenangkan persaingan tersebut adalah dengan melakukan upaya reformulasi kepemimpinan pesantren. Kepemimpinan pesantren merupakan aspek kehidupan yang menjadi perhatian banyak orang sejak puluhan tahun yang lalu. Kepemimpinan pesantren merupakan sebuah posisi sekaligus karya luhur yang memang dibutuhkan sebagai kodrat sejarah dan fitrah peradaban pesantren. Kepimimpinan dibutuhkan untuk terkelolanya pesantren, dengan arahan yang jelas, serta keadilan yang merata. Kepemimpinan pesantren memiliki ciri khas yang tidak dimiliki oleh kepemimpinan dalam organisasi dan lembaga pendidikan lainnya. Hal ini terindikasi dari eksistensi pesantren yang semakin menguat dari hari ke hari. Yang menjadi pertanyaan besar adalah bagaimana kepemimpinan pesantren dalam menghadapi perubahan sosial? Adakah terobosan-terobosan penting untuk mengembangkan daya saing syar'iy?
\end{abstract}

Kata Kunci: pengembangan daya saing syar'iy, kepemimpinan pesantren 


\begin{abstract}
In the last decade, the process of globalization and various new innovations have occurred in various fields of life. One of the effects of globalization is that pesantren as a place to explore and produce religious knowledge need to compete for survival. The competition includes quality, price, service, santri achievements and output. The winners of the competition are pesantren that have quality human resources in faith, piety, ability, science, technology and skills. One way to win the competition is to make efforts to reformulate pesantren leadership. Pesantren leadership is an aspect of life that has been a concern for many people since decades ago. Pesantren leadership is a position as well as noble work that is indeed needed as a historical nature and nature of pesantren civilization. Leadership is needed for the management of pesantren, with clear direction, and equitable justice. Pesantren leadership has a characteristic that is not possessed by leadership in other organizations and educational institutions. This is indicated by the existence of pesantren which are getting stronger gradually. In its objective conditions many pesantren cannot formulate their leadership well so they cannot develop their competitiveness based syar'iat of Islam. The most in important question is how is the leadership of the pesantren in facing social change? Are there important breakthroughs to develop syar'iy competitiveness?
\end{abstract}

Key Words: developing syar'iy competitiveness, pesantren leadership

\title{
Pendahuluan
}

Tipologi pesantren dipandang dari lembaga pendidikan yang diselenggarakan olehnya, dapat diklasifisikan menjadi empat tipe (1) Pesantren yang menyelenggaran pendidikan formal dengan menerapakan kurikulum nasional (2) Pesantren yang menyelenggarakan pendidikan keagamaan dalam bentuk madrasah dan mengajarkan ilmu-ilmu umum meski tidak menerapkan kurikulum Nasoional (3) Pesantren yang mengajarkan ilmu-ilmu agama dalam bentuk madrasah diniyah (4) pesantren yang hanya sekedar menjadi tempat pengajian. ${ }^{1}$

Tipologi pesantren juga dapat dikelompokkan menjadi pesantren salafiyah (pesantren yang mengajarkan kutub at- turath saja), pesantren khalafiyah (pesantren modern) dan pesantren kombinasi (memadukan salafiyah dan khalafiyah). Keberagaman tipologi pesantren tersebut berimbas pada keberagamaan

1 Sulthon Masyhud dan Moh. Khusnuridho, Manajemen Pondok Pesantren, (Jakarta: Difa Pustaka, 2003), 5. 
kepemimpinan pesantren. Di samping itu hal tersebut menuntut pesantren mengembangkan daya saingnya dengan segala tipologinya.

Pada kondisi obyektifnya, banyak pemimpin pesantren yang kurang memahami tentang hal-hal yang sangat urgen berkaitan dengan kepemimpinan, seperti prinsip-prinsip, falsafah dan teori kepemimpinan. Sebagai konsekuensi logisnya masih banyak pemimpin pesantren yang kurang memahami tentang pengembangan daya saing pesantren, baik pada tataran ideal maupun institusional. Sementara hal tersebut mutlak diperlukan agar pesantren dapat mempertahankan eksistensinya di tengah persaingan global.

Dengan demikian, pembahasan tentang reformulasi kepemimpinan pesantren melalui pengembangan daya saing pesantren perlu dilakukan, agar dapat dijadikan prototype bagi pesantren lain yang memiliki tipologi yang sama dan bagi pesantren yang memiliki tipologi berbeda, tapi berkeinginan merubah tipologinya.

\section{Pembahasan}

\section{Landasan Teologis Normatif Kepemimpinan Pesantren}

Kepemimpinan di Pesantren dilaksanakan sesuai dasar-dasar kepemimpinan Islam. Pertama, tidak mengangkat Pemimpin dari orang-orang yang mempermainkan Islam karena hal ini sudah diingatkan oleh Allah dalam QS. Al-Maidah 57:

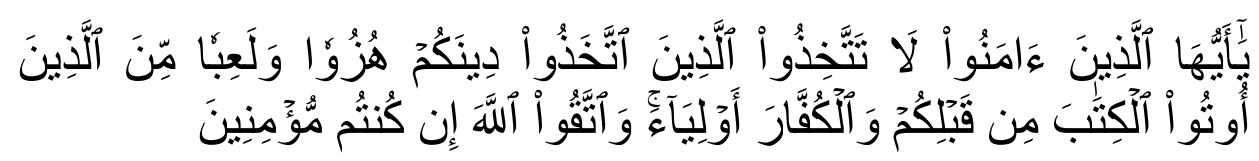

Artinya: Hai orang-orang yang beriman, janganlah kamu mengambil Jadi pemimpinmu, orang-orang yang membuat agamamu Jadi buah ejekan dan permainan, (yaitu) di antara orang-orang yang telah diberi kitab sebelummu, dan orang-orang yang kafir (orangorang musyrik). dan bertakwalah kepada Allah jika kamu betul-betul orang-orang yang beriman.

Kedua, pemimpin harus memiliki keahlian dalam bidangnya berkaitan dengan pemberian tugas, wewenang dan fungsi manajemen lainnya. Jika memberikan wewenang kepada yang tidak 
ahli maka akan mengakibatkan kerusakan kepada organisasi terkait. Dalam sebuah hadist disebutkan "Apabila suatu urusan diserahkan kepada yang bukan ahlinya, maka tumbulah saat kehancurannya."

Ketiga, pemimpin harus bisa diterima, mencintai dan dicintai umatnya, mendoakan dan didoakan oleh umatnya. Hal ini sesuai dengan firman Allah QS. Ali-Imron 159

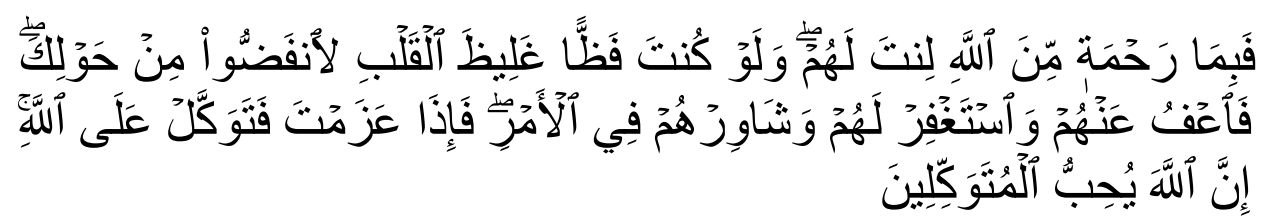

Artinya: Maka disebabkan rahmat dari Allah-lah kamu Berlaku lemah lembut terhadap mereka. Sekiranya kamu bersikap keras lagi berhati kasar, tentulah mereka menjauhkan diri dari sekelilingmu. karena itu ma'afkanlah mereka, mohonkanlah ampun bagi mereka, dan bermusyawaratlah dengan mereka dalam urusan itu kemudian apabila kamu telah membulatkan tekad, Maka bertawakkallah kepada Allah. Sesungguhnya Allah menyukai orang-orang yang bertawakkal kepada-Nya.

Keempat, pemimpin harus mengutamakan, membela dan mendahulukan kepentingan umat, melakukan supremasi hukum, melaksanakan syariat, berjuang menghapus segala bentuk kemungkaran, kekufuran, kekacauan dan fitnah. Dasar keempat ini sesuai dengan surah Al-Maidah: 8.

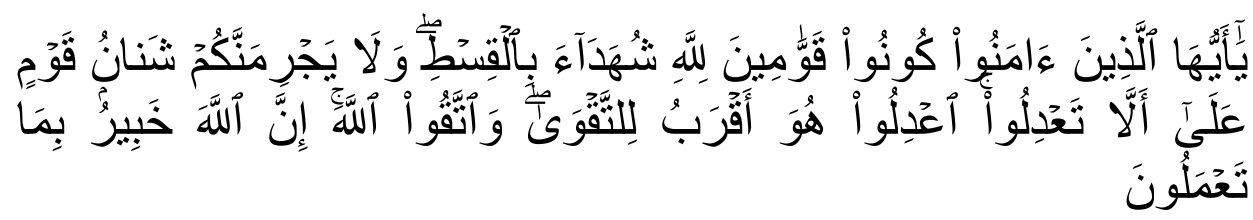

Artinya: Hai orang-orang yang beriman hendaklah kamu Jadi orangorang yang selalu menegakkan (kebenaran) karena Allah, menjadi saksi dengan adil. dan janganlah sekali-kali kebencianmu terhadap sesuatu kaum, mendorong kamu untuk Berlaku tidak adil. Berlaku adillah, karena adil itu lebih dekat kepada takwa. dan bertakwalah kepada Allah, Sesungguhnya Allah Maha mengetahui apa yang kamu kerjakan. 


\section{Prinsip-Prinsip dan Falsafah Kepemimpinan Pesantren}

Prinsip-prinsip kepemimpinan pesantren sama halnya dengan prinsip-prinsip kepemimpinan sebagaimana yang diajarkan oleh Nabi (prinsip kepemimpinan profetik) sebagai berikut:

1. Prinsip tauhid. Pemimpin pesantren harus dapat mengajak personil pesantren yang ia pemimpin ke arah satu kesatuan tauhid. Karena tauhid merupakan landasan terpenting dalam menjalankan kepemimpinan pesantren dan mempersatukan personil pesantren dengan ummat Islam pada umumnya.

2. Prinsip Syura (musyawarah). Kata Syura tidak identik dengan demokrasi, meskipun keduanya mebenarkan keputusan pendapat mayoritas. Dalam pesantren, keputusan pendapat mayoritas tidak boleh bertentangan dengan syari'at dan harus tetap memberikan ruang gerak bagi minoritas. Pendapat minoritas tetap menjadi pertimbangan bagi pembuatasan keputusan yang lain. Dengan demikian, pengambilan keputusan pendapat mayoritas tidak mutlak.

3. Prinsip al-Adalah (adil). Prinsip ini sangat penting, karena dapat menebarkan rasa cinta dan kasih sayang di antara personil pesantren. Keadilan dapat diartikan persamaan hak, tidak membedakan satu sama lain dalam memberikan haknya. Keadilan dapat juga diartikan kesesuaian dan keseimbangan dalam pemberian hak. Pemberian hak ini disesuaikan dengan fungsi yang diharapkan, kemampuan dan kesempatan yang dimiliki.

4. Prinsip al-Hurriyah (kebebasan). Pesantren menerapkan prinsip kebebasan yang bertanggung jawab dan kebebasan yang dibatasi kebebasan orang lain. Pesantren memberikan kebebasan pada personil di dalamnya untuk beribadah, berpendapat, bersikap, bertingkah laku, berkreasi dan berkarya, selama tidak bertentangad dengan peraturan pesantren yang telah disepakati bersama. ${ }^{2}$

Kepemimpinan pesantren mengandung falsafah kepemimpinan Gembala 4 M yaitu:

1. Mengenal. Pemimpin pesantren mengenal santri bukan hanya mengenal nama dan fisiknya, tapi juga mengenal latar

${ }^{2}$ Shoni Rahmatullah Amrozi, The Power Of Rasulullah's Leadership (Yogyakrta: Sabil, 2012), 142-157. 
belakang keluarganya bahkan seluruh aspek kepribadian dan perkembangannya.

2. Mengasuh. Dalam hal ini pemimpin pesantren berperan sebagai pengasuh bagi santrinya sebagaiman orang tua terhadap anaknya. Misalnya memperhatikan kesehatan, prilaku dan pergaulannya.

3. Mengayomi. Pemimpin pesantren mengayomi santrinya, sebagaiman seorang atasan mengayomi bawahannya. Seperti, mengembangkan potensi, bakat dan minatnya.

4. Melindungi. Pemimpin pesantren melindungi santrinya dari hal-hal yang membahayakan fisik dan jiwanya. ${ }^{3}$

Di samping itu kepemimpinan pesantren mengandung falsafah kepemimpinan $4 \mathrm{~K}$. Pertama, kepekaan, yaitu pemimpin pesantren diharapkan peka terhadap masalah yang muncul di dalam dan di luar pesantren. Kedua, kepeduliaan, yaitu kepekaan tidak ada artinya jika tidak memiliki kepedulian untuk membantu menyelesaikannya. Ketiga, keadilan, yaitu memberikan hak pada yang berhak menerimanya. Kepedulian harus diwujudkan dengan penuh keadilan. Keempat, kejujuran, yaitu suatu sifat mulia yang akan membawa pada kebaikan, baik pada pesantren maupun masyarakat Islam secara luas. ${ }^{4}$

Dari awal tinggal di pesantren, santri sudah berlatih memiliki kepekaan, kepedulian, kejujuran dan keadilan. Hal ini semakin dapat dirasakan, jika santri berkhidmat dalam kepemimpinan dan manajemen pesantren. Konsekwensi logisnya, santri memiliki kesiapan mental dan kecakapan untuk berkiprah dalam kepemimpinan masyarakat secara luas.

\section{Teori Kepemimpinan Pesantren}

Paling tidak ada tiga teori kepemimpinan yang dijadikan sebagai landasan gerak pesantren. Pertama, teori kepemimpinan spiritual, yaitu kepemimpinan yang berbasis pada etika religius, kejujuran sejati, fairness (kjujuran), pengenalan diri sendiri, fokus pada amal shaleh, spiritualisme yang tidak dogmatis, bekerja lebih efisien, membangkitkan yang terbaik dalam diri sendiri dan orang lain, keterbukaan menerima perubahan, visionar (memiliki

3 E.B Surbakti, Manajemen dan Kepemimpinan Hati Nurani (Jakarta: Kompas Gramedia, 2012), 163-185.

${ }^{4}$ E.B Surbakti, Manajemen..., 187-196. 
pandangan jauh ke depan), tetapi fokus pada persoalan didepan mata, doing the raight thing (melakukan sesuatu yang benar),disiplin tapi tetap fleksibel, santai dan cerdas, dan kerendahan hati. 5

Kedua, teori kepemimpinan hati nurani, yakni kepemimpinan yang memiliki karakteristik sebagai berikut Hikmat, Empati, Aktif Rendah hati dan Tanggap (HEART), ${ }^{6}$ sehingga membentuk rasa saling menghormati, memahami, rasa hubungan kesatuan dan ikatan yang lebih kuat. ${ }^{7}$ Ketiga, teori kepemimpinan profetik didasarkan pada sifat wajib bagi nabi yaitu shiddiq (jujur), amanah (dapat dipercaya), tabligh (menyampaikan wahyu) dan fathanah (cerdas). ${ }^{8}$

Munculnya teori kepemimpinan pesantren ini, bukan berarti pesantren mengabaikan teori kepemimpinan lainnya, seperti teori dasar kepemimpinan yang meliputi teori genetik, teori sifat dan teori perilaku. Hal ini juga bukan berarti pesantren mengabaikan teori kepemimpinan modern seperti teori kontingensi, teori partisipatif, teori kepemimpinan interaktif, teori kepemimpinan karismatik, teori kepemimpinan visioner, teori kepemimpinan transformasional dan sebagainya. Teori-teori kepemimpinan tersebut tetap diterapkan di pesantren, selama penerapannya tidak bertentangan dengan syariat Islam dan sesuai dengan kondisi pesantren serta memungkinkan untuk diterapkan di dalamnya.

Kepemimpinan pesantren seharusnya memiliki arah pengembangan daya saing pada terbentuknya: (1) umat yang bersatu (ummatan wahidah), (2) umat yang moderat (ummatan wasathan), (3) umat yang terbaik (khoiru ummah), (4) negara yang makmur (baldatun thayyibatun), dan (5) umat yang lurus di jalan Allah (ummatan muqtasidah). ${ }^{9}$

Kepemimpinan pesantren juga dapat mengarahkan dan mengembangkan daya saingnya menuju hal-hal berikut: (1) membentuk umat (takwin al-ummah), (2) membentuk kepribadian (takwin al-syakhshiyyah), (3) membentuk semangat berjamaah 2012), 11.

5Tobroni, The Spiritual Leadership (Malang: UMM Press, 2005), 26.

${ }^{6}$ Surbakti, manajemendankepemimipinahatinurani (Jakarta:Gramedia,

7Jack Canfield, The success Principles terj. RinaBuntaran (Jakarta: GramediaPustakaUtama, 2006), 478.

${ }^{8}$ Muhammad Syafii Antonio, Prophetic Leadership dan Management Wisdom (Jakarta: Tazkia Publishing, 2005), 2.

${ }^{9}$ Ali Nurdin, Quranic Society (Jakarta: Erlangga, 2006), 100. 
(takwin ruh al-jamaa'ah), (4) gerakan penyelamatan (harakah alinqaadz), (5) orang yang mendapatkan petunjuk (al-muhtaduun), dan (6) kesuksesan (al-falah). ${ }^{10}$

\section{Pengembangan Daya Saing Syar'iy Sebagai Terobosan}

Tidak ada pesantren yang selalu unggul, sebagaimana tak ada perusahan yang selalu unggul. Dalam perjalanannya yang berliku, pemimpin pesantren terkadang melakukan hal-hal yang cerdas, terkadang melakukan hal yang sebaliknya. Harus diakui, pesantren perlu melibatkan diri dalam persaingan global dan harus memenangkan persaingan tersebut, agar dapat mempertahankan eksistensinya.

Menyikapi hal tersebut, banyak pesantren yang harus bersaing dalam ruang pasar yang sudah ada, mengeksploitasi permintaan konsumen dan simpatisan pesantren dan harus memilih antara nilai dan biaya. Ketika ingin meningkatkan nilai dan kualitas pendidikannya, pesantren harus mengeluarkan biaya yang sangat besar. Ketika biaya tidak mencukupi dan tidak mengimbangi, pesantren harus melakukan usaha berdarah-darah untuk mempertahankan nilai dan kualitasnya.

Penulis memandang usaha apapun yang ditujukan untuk mampu membangun dan mengembangkan daya saing pesantren merupakan suatu hal yang patut mendapatkan apresiasi dan elaborasi secara memadai. Harus diakui, hal ini memerlukan kritik, upaya rekonstruksi, perubahan bahkan dekonstruksi pemikiranpemikiran yang sudah ada.

Sepintas lalu hal itu mudah dilakukan. Akan tetapi ketika kita mencoba masuk semakin menukik ke dalam akan terlihat persoalan-persoalan yang muncul atau barangkali akan tetap muncul di masa mendatang.

Untuk menghadapi persoalan-persoalan yang muncul, pemimpin pesantren perlu memperbaiki kualitas keunggulan. Karena itu pemimpin pesantren perlu mempelajari dan memahami apa yang telah dilakukan di masa lampau, sehingga nampaklah tindakan positif yang harus diulang secara sistematis dan tindakan negatif yang harus ditinggalkan. Inilah yang disebut langkah strategis yang cerdas.

${ }^{10}$ Irwan Prayitno, Datuak Rajo Bandaro Basa, Kepribadian Dai (Jakarta: Pustaka Tarbiatuna, 2005), 291. 
Langkah strategis pertama adalah menciptakan strategi samudera biru (blue ocean strategy). Dalam hal ini pemimpin pesantren perlu menciptakan ruang pasar yang belum ada pesaingnya. Dengan demikian pemimpin pesantren tidak perlu sibuk memikirkan cara memenangkan persaingan, karena dalam hal ini, persaingan bukanlah hal yang relevan dalam pesantren yang dipimpinnya. Dengan strategi ini, pemimpin pesantren dituntut untuk mampu memadukan keseluruhan sistem kegiatan pesantren dalam mengejar diferensiasi dan biaya rendah. ${ }^{11}$

Secra tekhnis, kerangka kerja blue ocean strategy ini didasarkan pada empat langkah, yaitu hapuskan, kurangi, tingkatkan dan ciptakan. Empat langkah ini dapat dilakukan dengan menjawab empat pertanyaan kunci sebagai berikut:

1. Faktor apa saja yang harus dihapuskan karena sudah dianggap tidak efektif dalam pelaksanaannya.

2. Faktor apa saja yang harus dikurangi hingga di bawah standar dan jika dilakukan dalam tingkat yang melebihi standar, akan menjadi tidak efektif?

3. Faktor apa saja yang harus ditingkatkan hingga diatas standar?

4. Faktor apa saja yang belum pernah ditawarkan sehingga harus diciptakan?

Langkah strategis kedua adalah menerapkan tiga strategi generik. Berdasarkan strategi ini, pemimpin pesantren perlu melakukan tiga hal, yaitu: keunggulan biaya menyeluruh, diferensiasi dan fokus. Dalam hal ini, pemimpin pesantren harus menyediakan biaya yang besar untuk meningkatkan kualitas pada semua aspek kepesantrenan. Di samping itu pemimpin pesantren harus mampu menampakkan diferensiasi pesantren yang dipimpinnya. Agar mendapatkan hasil yang maksimal, maka pemimpin pesantren perlu fokus terhadap diferensiasi yang disepakati dan membuat moto pesantren yang memikat. ${ }^{12}$

Langkah strategis ketiga adalah melakukan reformulasi kepemimpinan pesantren dengan mengembangkan daya saing syar'iy di dalamnya. Daya saing syar'iy pesantren adalah

"W.Chan Kim, Renee Mauborgne, Blue Ocean Strategy, Strategi Samudera Biru (Jakarta: Serambi Ilmu Semesta, 2005), 38

${ }^{12}$ Michael E. Porter, Strategi Bersaing (Competitive Strategy) (Tangerang: KARISMA, 2007), 71 
kemampuan personil pesantren untuk menunjukkan keunggulan dalam hal tertentu dengan cara memperlihatkan situasi dan kondisi yang paling menguntungkan, hasil kerja yang lebih baik, lebih cepat atau lebih bermakna dibandingkan dari lainnya berdasarkan syari'at Islam

Dalam melihat persoalan pengembangan daya saing pesantren perlu digunakan dua tataran institusional dan tataran ideal. Pada tataran institusional akar-akar daya saing di pesantren sudah ada, sekalipun sangat sederhana dan perlu dikembangkan. Sedangkan dari tataran ideal (visi), kita agak mengalami kesulitan, sebab sebuah visi pesantren menuntut adanya kemampuan dan kesiapan pemimpin dan seluruh personil di dalamnya untuk menyerap khazanah dari luar sehingga muncul sinergi antara khazanah Islam dengan khazanah luar.

\section{Pengembangan Daya Saing Syar'iy pada Tataran Ideal}

Pemimpin pesantren diseyogyakan mampu mengembangkan daya saing pesantrennya menuju tujuan syariah (maqashid asysyari'ah) yaitu: menjaga agama, jiwa, harta, akal, harga diri dan keturunan. ${ }^{3}$ Pengembangan daya saing syar'iy harus didasarkan pada asas-asas yang termaktub dalam Al-Qur'an Surat At-Taubah Ayat 105 tentang anjuran terus beramal dan berkarya, Al-Qur'an surat Al-Baqarah Ayat 148 tentang berlomba-lomba dalam kebaikan, Al-Qur'an surah Ali Imron ayat 104 tentang anjuran mengajak pada kebaikan dan amar ma'ruf nahi munkar dan $\mathrm{Al}$ Qur'an surah Ali Imron ayat 110 tentang anjuran untuk menjadi khair ummah yang beriman pd Allah dan amar ma'ruf nahi munkar.

Di samping itu pemimpin pesantren harus mampu menegakkan pilar-pilar pengembangan daya saing syar'iy sebagai berikut: menguasai teoritis, membangun ruhiyah, membangkit-kan fikrah, memahami lapangan, menyusun langkah, mengokohkan stuktur dan membangkitkan gerakan dan tindakan nyata. ${ }^{14}$

Adapun pengembangan daya saing syar'iy memiliki karakteristik sebagai berikut yaitu: sistematis (المنهجية) sehingga

${ }^{13}$ Abdur Rahman An- Nahlawi, Ushul At- Tarbiyah Al- Islamiyah wa Asalibaha (Indonesia: Dzar al- Fikri,1986), 69-74

${ }^{14}$ Ummu Yasmin, Agenda Materi Tarbiyah Panduan kurikulim Da'i dan Murabbi (Surakarta : Media Insani 2002), 169 
semua masalah dapat terselesaikan dengan baik.. ${ }^{15}$ Bertahap (المرحلية) sehingga apa yang ia lakukan dapat berjalan dengan baik sesuai dengan perencanaan yang matang, Modern (العصرية) karena kita tidak akan lepas dari era globalisasi dan akibat baik buruk yang ditimbulkannya dan perubahan (اللإنقلابية). ${ }^{16}$

Pemimpin pesantren sebagai pelaku pengembangan daya saing syar'iy hendaknya memiliki karakteristik sebagai berikut yaitu: الفهم (pemahaman yang baik), الاخلاص (ikhlas karena Allah) ${ }^{17}$, العمل (membuktikan ucapannya dengan amal) الجهاد الإص ( memperjuangkan agama), التضحية (berani berkorban untuk kepentingan bersama), الثبات والمرونة (berteguh hati dan fleksibel), التجرد (focus terhadap apa yang diharapkannya), الاخوة (bertekad untuk memperkuat persaudaraan Islam), الثقة( dapat dipercaya), : الريانية( sikap dan tingkah lakunya karena Allah, berdasarkan syari'at Allah, untuk mendapatkan keridhoan Allah), الثبات والمرونة (Berteguh hati pada kondisi tertentu dan fleksibel pada kondisi yang lain), الشمولية (Pandangan berfikirnya komprehensif dengan mempertimbangkan beberapa aspek kehidupan), التوازان (Pandangan berfikirnya seimbang dan proporsional tentang kehidupan di dunia dan akhirat, tentang kepentingan pribadi dan bersama), الايجابية (Positive thinking terhadap segala perubahan di masyarakat dan responsif terhadapnya), الواقعية (Realistis sehingga solusi yang didapatkan ketika berhadapan dengan satu masalah dapat diimplementasikan dengan baik) ${ }^{19}$.

Dari pembahasan tersebut, dapat difahami bahwa pengembangan daya saing syar'iy di pesantren melalui reformulasi kepemimpinan pesantren dapat diilustrasikan sebagai berikut:

15 Muhammad Syadid, Manhaj Al- Quran Fit Tarbiyah (Suriah: Muassasah Ar- Risalah, 1979), 146-152

${ }^{16}$ An- Nahlawi, Ushul , 146

${ }^{17}$ Muhammad Jamaluddin, Mauidhotul Mukminin ( tt, Dzar al- Fikri, tt), 368

18 Abi Hamid Muhammad bin Muhammad al-ghozali, Maqaamaat AlUlama' ( Liban, Dzar al-Kutub Al- Ilmiyah, 2003), 95

${ }^{19}$ WAMY. Al-Mausu'ah Al-Muyassaroh fi Al-Adyani wa Al-Madzahibi Al Mu'asiroh ( Riyad: An-Nadwah Al-'Alamiyah li As-Syabab Al-Islami, 1972). 28 


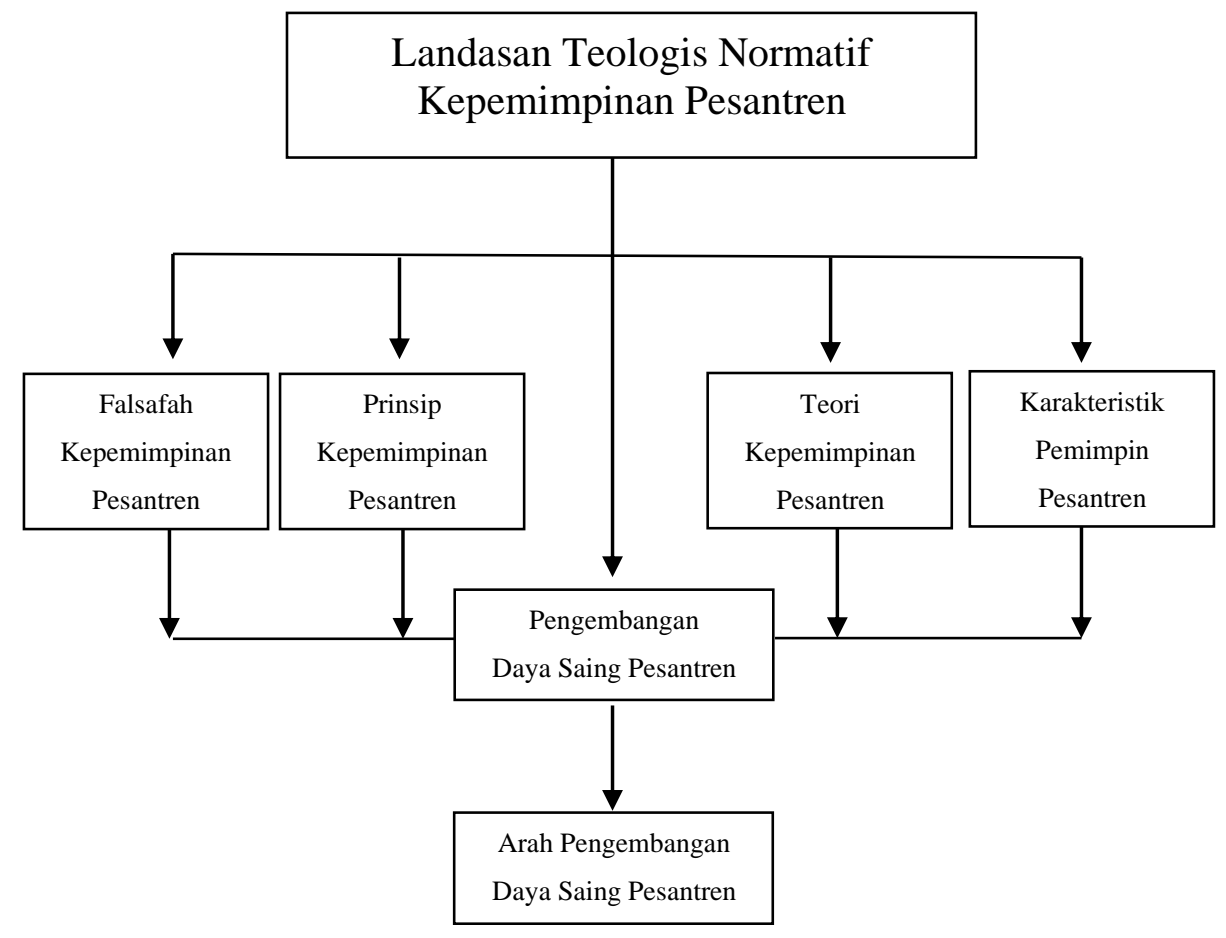

Gambar 1. Framework Pengembangan Daya Saing Syar'iy di Pesantren pada Tataran Ideal

\section{Pengembangan Daya Saing Syar'i pada Tataran Institusional}

Pada tataran institusional, pemimpin pesantren seharusnya menerapkan pengembangan daya saing syar'iy dengan cara: Pertama, memperkuat orientasi pesantren sehingga menjadi pesantren berbasis budaya nilai Islam. Dengan orientasi ini maka pesantren akan berhasil memperkuat keimanan dan moralitas santri.

Kedua, membentuk pesantren yang memiliki spesialisasi tertentu seperti pesantren sains, pesantren al-Qur'an, pesantren alHadits, pesantren Fiqih dan sebagainya, sehingga santri ahli dalam bidang tertentu.

Ketiga, mengefektifkan program tugas mengajar di pesantren lain atau di lembaga pendidikan yang membutuhkannya, sebagai syi'ar pesantren dan upaya pengembangan dakwah Islam. Hal ini dapat mengembangkan daya saing pesantren melalui demonstrasi product pendidikan pesantren. 
Keempat, mengefektifkan program tugas belajar bagi santri, agar santri memiliki kesempatan untuk melanjutkan study di jenjang pendidikan selanjutnya dan kembali ke pesantren untuk mengamalkan ilmunya serta berkhidmah pada pesantren. Dengan demikian, program ini bukan hanya dapat meningkatkan kualitas santri, tapi secara tidak langsung juga meningkatkan kualitas pesantren.

Kelima, optimalisasi program penerbitan sebagai media dakwah dan penguatan budaya tulis di pesantren. Di pesantren, budaya tutur lebih kuat daripada budaya tulis. Hal ini sangat disayangkan, karena pada realitasnya, product budaya tulis lebih monumental dari pada product budaya tutur. Product budaya tulis dapat dimanfaatkan oleh masyarakat luas dari generasi ke generasi dan dari zaman ke zaman.

Keenam, program pendidikan pesantren harus integratif dengan program pendidikan madrasah, baik secara vertikal maupun secara horizontal, agar dapat saling mendukung dan melengkapi dalam penyelenggaraan program tersebut.. Contoh program pendidikan pesantren harus integratif secara vertikal, yaitu pengadaan madrasah diniyah dari tingkat ula, wustha dan ulya dan pengadaan pengajian kitab kuning dari level terendah sampai level tertinggi dengan kurikulum yang berkelanjutan. Contoh program pendidikan pesantren harus integratif secara horizontal yaitu pelaksanaan madrasah diniyah dijadikan syarat kelulusan dalam pendidikan formal/ madrasah yang diselenggarakan pesantren.

Ketujuh, kerjasama dengan pesantren lain, baik didalam maupun di luar negeri. Hal ini dimaksudkan untuk mengembangkan manajemen dan kualitas pesantren, sehingga kualitas santri dan output pesantren juga akan meningkat. Dengan demikian, hal tersebut dapat mengembangkan daya saing pesantren dan syi'ar pesantren di kalangan masyarakat.

Kedelapan, penguatan bahasa asing. Sebuah idiom yang sangat dikenal dalam dunia perguruan tinggi adalah "Language is part of culture and culture is part of language". Artinya, bahasa adalah bagian dari budaya dan budaya adalah bagian dari bahasa. Hal ini menunjukkan bahwa bahasa adalah hal yang sangat penting bagi manusia dalam kehidupan berbudaya dan berperadaban, karena bahasa mengungkapkan nilai, keyakinan dan pandangan hidup manusia. Semakin tinggi budaya dan peradaban suatu bangsa, maka semakin tinggi penghargaan mereka terhadap bahasa. 
Sebaliknya semakin tinggi penghargaan mereka terhadap bahasa, maka semakin tinggi budaya dan peradaban mereka. Pesantren yang menjujung tinggi bahasa internasional akan dapat mencetak santri yang memiliki paradigma pemikiran, wawasan, budaya, peradaban, medan dakwah berskala internasional. Dengan demikian, daya saing pesantren ini juga akan dapat dikembangkan sampai pada tingkat internasional.

Kesembilan, optimalisasi pengeloaan perpustakaan pesantren. Perpustakaan bukan hanya tempat menyimpan dan mendistribusikan buku-buku dan kitab-kitab. Perpustakaan juga bukan sekedar tempat santri mengerjakan tugas sekolah, tapi lebih dari itu, perpustakaan merupakan tempat untuk mengkaji dan mendiskusikan ilmu yang diajarkan oleh kyai dan ustadz.

Kesepuluh, pesantren harus lebih akomodatif terhadap perkembangan zaman untuk perkembangan madrasah atau sekolah yang berada di bawah naungannya. Hal ini dapat dilakukan dengan sering melakukan studi komparatif pada sekolah dan pesantren lain yang layak untuk dijadikan prototype dalam bidang yang ingin dipelajari.

Kesebelas, peningkatan profesionalisme SDM pesantren yang diukur dengan tiga hal berikut: Kafa'ah yaitu adanya keahlian dan kecakapan dalam bidang pekerjaan yang dilakukan, Himmatul 'amal yaitu memiliki semangat atau etos kerja yang tinggi dan Amanah yaitu terpercaya dan bertanggungjawab dalam menjalankan berbagai tugas dan kewajibannya. ${ }^{20}$

Semua langkah-langkah tersebut dianalisis dan hasil analisisnya dipetakan sesuai kerangka kerja blue ocean strategy dengan terlebih dahulu menjawab empat pertanyaan kuncinya. Adapun pemetakannya dapat divisualisasikan sebagai berikut:

Tabel 1. Framework Pengembangan Daya Saing Syar'iy di Pesantren pada Tataran Institusional

\begin{tabular}{|l|l|}
\hline Menghapuskan & Meningkatkan \\
1. & 1. \\
2. & 2. \\
3. dan seterusnya & 3. dan seterusnya \\
\hline
\end{tabular}

${ }^{20}$ Abdullah 'Ulwaan, Tarbiyah Al- Aulaad fil Islam Juz I (tt, Dzar AsSalam, 1893), 357 


\begin{tabular}{|l|l|}
\hline Mengurangi & Menciptakan \\
1. & 1. \\
2. & 2. \\
3.dan seterusnya & 3.dan seterusnya \\
\hline
\end{tabular}

\section{Simpulan}

Pengembangan daya saing syar'iy mutlak diperlukan dalam reformulasi kepemimpinan pesantren baik pada tataran ideal maupun tataran institusional. Sebagai pelaku pengembangan daya saing pesantren, pemimpin pesantren dituntut untuk memiliki sejumlah karakteristik pemimpin pesantren, agar pesantren yang dipimpinnya dapat mencapai tujuannya dan memenangkan persaingan pendidikan global. Kendatipun pengembangan daya saing ini sudah dilakukan oleh beberapa pesantren tetapi pemimpin pesantren perlu meninjau kembali dan lebih memahami tentang landasan teologis normatif kepemimpinan pesantren, prinsipprinsip, falsafah dan arah pengembangan kepemimpinan pesantren. Pemimpin pesantren juga perlu menguasai tentang teori-teori kepemimpinan, baik teori kepemimpinan klasik, kontemporer maupun kepemimpinan pesantren, sebagai landasan dalam merumuskan langkah-langkah pengembangan daya saing syar'iy di pesantren.

\section{Referensi}

Amrozi, Shoni Rahmatullah. The Power of Rasulullah's Leadership. Yogyakrta: Sabil, 2012.

Antonio, Muhammad Syafii. Prophetic Leadership dan Management Wisdom. Jakarta: Tazkia Publishing, 2005.

Canfield, Jack. The Success Principles. Terj. Rina Buntaran. Jakarta: Gramedia Pustaka Utama, 2006.

E.B Surbakti. Manajemen dan Kepemimpinan Hati Nurani Jakarta: Kompas Gramedia, 2012.

Indrajit, Eko R. Djokopranoto. Manajemen Perguruan Tinggi Modern. Yogyakarta, ANDI, 2006.

Jamaluddin, Muhammad, Mauidhotul Mukminin. tt, Dar al- Fikri, tt. 
Kim,W.Chan and Renee Mauborgne. Blue Ocean Strategy, Strategi Samudera Biru. Jakarta: Serambi Ilmu Semesta, 2005.

Masyhud, Sulthon, Moh. Khusnuridho. Manajemen Pondok Pesantren. Jakarta: Difa Pustaka, 2003.

Muhammad bin Muhammad al-ghozali, Abi Hamid. 2003. Maqaamaat Al-Ulama'. Liban, Dar al-Kutub Al- Ilmiyah.

Nurdin, Ali. Quranic Society. Jakarta: Erlangga, 2006.

Porter, Michael E. Strategi Bersaing (Competitive Strategy).Tangerang: Karisma, 2007.

Prayitno, Irwan, Datuak Rajo Bandaro Basa. Kepribadian Dai. Jakarta: Pustaka Tarbiatunam, 2005..

Rahman An- Nahlawi, Abdur. Ushul At- Tarbiyah Al- Islamiyah wa Asalibaha. Indonesia: Dar al- Fikri, 1986.

Sobahar, Abd Halim. Kebijakan Pendidikan Islam dari Ordonansi Guru sampai UU Sisdiknas. Jakarta: Raja Grafindo Persada, 2013.

Surbakti. Manajemen dan Kepemimipinan Hati Nurani. Jakarta:Gramedia, 2012.

Syadid, Muhammad. Manhaj Al- Quran Fit Tarbiyah ( Suriah: Muassasah Ar- Risalah, 1979.

Tobroni. The Spiritual Leadership. Malang: UMM Press, 2005.

Ulwan, Abdullah. Tarbiyah Al- Aulaad fil Islam Juz I . tt, Dar AsSalam, 1893.

Wahid, Abdur Rahman. Prisma Pemikiran Gus Dur. Yogyakarta: LkiS, 1999.

Walters, J. Donald, Herb Cohen, Dave Johnson. Great Leadership. Semarang: Dahara Prize, 2013.

WAMY. Al-Mausu'ah Al-Muyassaroh fi Al-Adyani wa Al-Madzahibi Al-Mu'asiroh. Riyad: An-Nadwah Al-'Alamiyah li As-Syabab Al-Islami, 1972.

Yasmin, Ummu. Agenda Materi Tarbiyah Panduan Kurikulim Da’i dan Murabbi. Surakarta : Media Insani, 2002.

Zuhri, Mustofa. Pendidikan Pesantren. Yogyakarta: Absolute Media, 2010. 
www.pendis.kemenag.go.id. Diakses 11 April 2018.

www.jatim.kemenag.go.id. Diakses 11 April 2018. 